\title{
Cadmium and Lead Concentration in Drinking Instant Coffee, Instant Coffee Drinks and Coffee Substitutes: Safety and Health Risk Assessment
}

\author{
Anna Winiarska-Mieczan ${ }^{1}$ (1) $\cdot$ Karolina Jachimowicz ${ }^{1} \cdot$ Svitlana Kislova $^{2} \cdot$ Małgorzata Kwiecień $^{1}$. \\ Zvenyslava Zasadna ${ }^{2} \cdot$ Dmytro Yanovych $^{2}$
}

Received: 3 January 2022 / Accepted: 20 January 2022 / Published online: 25 January 2022

(C) The Author(s) 2022

\begin{abstract}
The presence of heavy metals in food is a global problem. The paper aimed to examine the content of cadmium $(\mathrm{Cd})$ and lead $(\mathrm{Pb})$ in instant coffee and instant coffee substitutes. The safety of consumption of the beverages by adult Poles was estimated based on the following parameters: tolerable weekly intake (TWI) \%, benchmark dose lower confidence limit (BMDL) \%, chronic daily intake (CDI), target hazard quotient (THQ) and hazard index (HI), for three beverage consumption patternsone, two or three servings a day. Forty-nine samples of coffee, instant coffee drinks and coffee substitutes were analysed. The content of cadmium and lead was determined by ICP (inductively coupled plasma) analysis. The maximum level of Cd in the analysed beverages was $3.2 \mu \mathrm{g}$, and that of $\mathrm{Pb}$ was $82.6 \mu \mathrm{g}$ per $1 \mathrm{~kg}$. The tolerable level of intake of $\mathrm{Cd}(\mathrm{TWI})$ and $\mathrm{Pb}$ (BMDL) with the analysed beverages did not exceed 2.5\%. The value of CDI, THQ and HI was not higher than 1, which means that the risk of diseases related to chronic exposure to $\mathrm{Cd}$ and $\mathrm{Pb}$ consumed with coffee should be evaluated as very low. However, special note should be taken of $\mathrm{Pb}$, as the level of this metal was higher than that of $\mathrm{Cd}$, and for beverages with a higher weight per serving (e.g. Cappuccino), the intake of $\mathrm{Pb}$ can exceed consumer-safe levels if they are consumed on a regular basis. Therefore, it should be considered whether it is advisable for flavoured multi-ingredient instant coffee drinks to be consumed from time to time only, and natural coffee with optional milk and/or sugar be the choice of regular coffee drinkers.
\end{abstract}

Keywords Instant coffee $\cdot$ Coffee substitutes $\cdot$ Cadmium $\cdot$ Lead $\cdot$ Safety

\section{Introduction}

Coffee is one of the most popular beverages around the world. Its popularity is due to both its flavour and aroma [1] and proven health benefits related to the presence of active antioxidants such as polyphenols, caffeine and diterpenes [2]. However, it is important to note the association of diterpenes with elevated plasma cholesterol and triglyceride levels, mainly through an increase in plasma low-density

Anna Winiarska-Mieczan

anna.mieczan@up.lublin.pl

1 Institute of Animal Nutrition and Bromatology, University of Life Sciences in Lublin, Akademicka 13, 20-950 Lublin, Poland

2 State Scientific-Research Control Institute of Veterinary Medical Products and Fodder Additives, Lviv, Ukraine lipoprotein (LDL) [2]. Regular drinking of moderate amounts of coffee (not more than 5 cups a day) protects the body against DNA damage and mitigates the risk of developing breast, prostate and colorectal cancer and many other chronic diseases (e.g. type 2 diabetes, Parkinson's, depression) [3-7]. More than $95 \%$ of adults in Poland, $61 \%$ in Italy and $78 \%$ in Spain are regular coffee drinkers $[1,6,8]$. Statistically, in 2019 in Poland, one person consumed $2.16 \mathrm{~kg}$ of coffee, that is, $0.18 \mathrm{~kg}$ per month [9]. This level of consumption has remained steady for several years. Poles most often drink 1-3 cups of coffee a day [1], Columbians on average 3.4 cups a day [10] and Ethiopians 4 cups a day [11]. Our surveys showed that in Poland, instant coffee was the choice of $32 \%$ of respondents, whereas $23 \%$ declared drinking beverages such as instant coffee drinks of the '2-in-1' or ' 3 -in-1' type, and decaffeinated coffee, cereal coffee and cappuccino [1]. Similarly, Chudy [8] and Czarniecka-Skubina et al. [12] demonstrated that about 50\% of coffee consumers in Poland 
drink instant coffee and coffee blends. Coffee beverages and flavoured coffees are most often the choice of young people aged 18-25 [12]. Instant coffee owes its popularity primarily to the fact that it is easy and quick to prepare. For many years, the trend of choosing instant coffee has remained high in Poland, despite the fact that natural coffee is perceived as real coffee by respondents, while instant coffee and coffee blends are regarded as non-natural and high-calorie products [13]. The difference between ground coffee and instant coffee is the content of caffeine. When one teaspoon of ground coffee is brewed, the cup contains $40 \mathrm{mg}$ of caffeine, and for one teaspoon of instant coffee, $60 \mathrm{mg}$ [14]. Moreover, instant coffee contains more polyphenols-ca. $61 \mathrm{mg}$ per $1 \mathrm{~g}$, and ground coffee less than $19 \mathrm{mg}$ per $1 \mathrm{~g}$ only. This difference is due to the processing method. Instant coffee has a higher content of minerals ( $\mathrm{Ca}, \mathrm{Mg}, \mathrm{Zn}, \mathrm{Fe}, \mathrm{Mn}, \mathrm{Al}, \mathrm{Cr}$ and $\mathrm{Ni}$ ) compared to the same amount of ground coffee [15].

Unfortunately, coffee also contains toxic heavy metals such as cadmium $(\mathrm{Cd})$ and lead $(\mathrm{Pb})$ [16-18], although available studies primarily cover instant coffee. The presence of heavy metals in food is a global problem. Despite available studies showing that the levels of $\mathrm{Cd}$ and $\mathrm{Pb}$ in food are normally safe for humans, heavy metals accumulate in the tissues of living organisms and have a long halflife (5-30 years for $\mathrm{Cd}$ and 30 days in soft tissue and up to 10 years in bones for $\mathrm{Pb}$ ) [19], so they pose a risk to health when supplied regularly, even in small amounts. Both $\mathrm{Cd}$ and $\mathrm{Pb}$ display a strong teratogenic, carcinogenic, mutagenic and embryotoxic effect [20]. As recommended by EFS, the tolerable weekly intake (TWI) of Cd should not exceed $2.5 \mu \mathrm{g} \mathrm{kg}^{-1}$ of body weight per week [21], and the benchmark dose lower confidence limit (BMDL) of $\mathrm{Pb}$ should not exceed $10.5 \mu \mathrm{g} \mathrm{kg}^{-1}$ of body weight per week (BMDL01atherogenic effect of $\mathrm{Pb}$ ) and $4.4 \mu \mathrm{g} \mathrm{kg}^{-1}$ of body weight per week (BMDL10-nephrotoxic effect of $\mathrm{Pb}$ ) [22]. The content of heavy metals is usually analysed in ground coffee; however, since the consumption of instant coffee and instant coffee drinks and that of natural coffee is comparatively high in Poland $[1,8,12]$, it is essential to evaluate whether it is safe to drink such beverages. The study aimed to measure the content of cadmium and lead in instant coffee, coffee drinks and instant coffee substitutes. In addition, it was also evaluated whether coffee drinks are safe for adult Poles in terms of their $\mathrm{Cd}$ and $\mathrm{Pb}$ content. The presented results form part of a project estimating the intake of minerals (toxic and essential) by the population of Poland.

\section{Material and Methods}

\section{Study Material}

Forty-nine samples of coffee, instant coffee drinks and coffee substitutes were analysed (Table 1). The coffee was bought at grocery stores in Chełm, Zamość and Lublin (eastern Poland) in August 2019. The samples were stored in sealed original packaging at room temperature until analyses.

\section{Chemical Analysis}

\section{Preparation of Samples for Analysis}

The samples were averaged by manual mixing. A sample of about $3 \mathrm{~g}$ was weighed in three replications into previously heat-sterilised china crucibles and then subjected to dry mineralisation in a muffle furnace at a temperature of $550{ }^{\circ} \mathrm{C}$ using hydrogen peroxide as an antioxidant-as described elsewhere [20]. The resulting ash was dissolved in $10 \mathrm{~mL}$ of $1 \mathrm{M} \mathrm{HNO}_{3}$.

Table 1 Quality control

\begin{tabular}{|c|c|c|}
\hline & $\mathrm{Cd}$ & $\mathrm{Pb}$ \\
\hline Blank sample & $1 \mathrm{M} \mathrm{HNO}_{3}$ & $1 \mathrm{M} \mathrm{HNO}_{3}$ \\
\hline Certified reference material (1) & INCT-TL-1 (Tea leaves) & INCT-TL-1 (Tea leaves) \\
\hline Certified reference material (2) & INCT-MPH-2 (Mixed Polish herbs) & INCT-MPH-2 (Mixed Polish herbs) \\
\hline \multicolumn{3}{|c|}{ Certified element concentration in CRM 1} \\
\hline Certified, $\mathrm{mg} \mathrm{kg}^{-1}$ & 0.030 & 1.78 \\
\hline Observed, $\mathrm{mg} \mathrm{kg}^{-1}$ & 0.029 & 1.76 \\
\hline Recovery rate, $\%$ & 98 & 99 \\
\hline \multicolumn{3}{|c|}{ Certified element concentration in CRM 2} \\
\hline Certified, $\mathrm{mg} \mathrm{kg}^{-1}$ & 0.199 & 2.16 \\
\hline Observed, $\mathrm{mg} \mathrm{kg}^{-1}$ & 0.189 & 2.22 \\
\hline Recovery rate, $\%$ & 95 & 103 \\
\hline Precision, $\%$ & 6.04 & 6.07 \\
\hline Replicates & 3 & 3 \\
\hline
\end{tabular}




\section{Determination of the Content of $\mathrm{Cd}$ and $\mathrm{Pb}$}

The content of cadmium and lead was determined by ICP (inductively coupled plasma mass spectrometry) in a Varian 820 MS Mass Spectrometer (Varian, Melbourne, Australia). Determination conditions were as follows: mass monitored $114(\mathrm{Cd}), 206,207,208(\mathrm{~Pb})$; plasma, argon; plasma gas flow $1.7 \mathrm{~L} \mathrm{~min}^{-1}$; RF power $1.37 \mathrm{~kW}$. The calibration curve was drawn using the following models: Cd (99.99\% purity; concentration of solutions $0.2,0.4,1$, 2, 4 and $10 \mu \mathrm{g} \mathrm{Cd} \mathrm{L}^{-1} 1 \% \mathrm{HNO}_{3}$ ), and $\mathrm{Pb}$ (99.99\% purity; concentration of solutions $0.1,0.2,0.5,1,2$ and $5 \mu \mathrm{g} \mathrm{Pb}$ $\mathrm{L}^{-1} 1 \% \mathrm{HNO}_{3}$ ). The results of measurements were verified against a blank sample $\left(1 \mathrm{M} \mathrm{HNO}_{3}\right)$ and certified reference materials-INCT-TL- 1 Tea leaves $(0.030 \mathrm{mg} \mathrm{Cd}$ and $1.78 \mathrm{mg} \mathrm{Pb}$ per $1 \mathrm{~kg}$ ) and INCT-MPH-2 Mixed Polish herbs $(0.199 \mathrm{mg} \mathrm{Cd}$ and $2.16 \mathrm{mg} \mathrm{Pb}$ per $1 \mathrm{~kg})$. The percentage of $\mathrm{Cd}$ and $\mathrm{Pb}$ recovered from the reference materials was $95-103 \%$, with the measurement precision being 6.04 for $\mathrm{Cd}$ and 6.07 for $\mathrm{Pb}$ (Table 1). The limit of detection (LOD) was $0.004 \mu \mathrm{g} \mathrm{kg}^{-1}$ for $\mathrm{Cd}$ and $0.005 \mu \mathrm{g} \mathrm{kg}^{-1}$ for $\mathrm{Pb}$. The limit of quantification (LOQ) was $0.01 \mu \mathrm{g} \mathrm{kg}^{-1}$ for $\mathrm{Cd}$ and $0.030 \mu \mathrm{g} \mathrm{kg}^{-1}$ for $\mathrm{Pb}$. Each chemical analysis was repeated three times.

\section{Reagents and Reference Materials}

Nitric acid (65\% ultra-pure $\mathrm{HNO}_{3}$ ) and hydrogen peroxide ( $30 \%$ pure $\mathrm{H}_{2} \mathrm{O}_{2}$ ) were purchased from POCH S.A. (Poland). The $\mathrm{Cd}$ and $\mathrm{Pb}$ standards were purchased from Merck (Germany). The certified reference materials INCTTL-1 and INCT-MPH-2 were purchased from the Institute of Nuclear Chemistry and Technology (Warsaw, Poland).

\section{Calculations}

The safety of drinking beverages was calculated for three patterns of consumption: one serving, two servings or three servings a day for 365 days in a year $[1,18]$. One serving was described as the quantity of the instant product recommended by manufacturers, as indicated on the packaging. For beverages in bulk packaging, one teaspoon of the powder was weighed, and for sachets, one serving corresponded to one sachet (Table 2).

\section{Estimation of Safety}

(1) Tolerable weekly intake (TWI) $\%$ and BMDL \% were calculated according to the formulas [18]:
$\% \mathrm{TWI}=\frac{\mathrm{EWI}_{\mathrm{Cd}} \times 100}{\mathrm{TWI}}$

TWI value: $2.5 \mu \mathrm{g} \mathrm{Cd} \mathrm{kg}^{-1}$ body weight per week [21]

$\% \mathrm{BMDL}=\frac{\mathrm{EWI}_{\mathrm{Pb}} \times 100}{\mathrm{BMDL}}$

BMDL values: BMDL01 was $10.5 \mu \mathrm{g} \mathrm{Pb}$ per kg ${ }^{-1}$ body weight per week and BMDL10 was $4.4 \mu \mathrm{g} \mathrm{Pb}$ $\mathrm{kg}^{-1}$ body weight per week [22]. The mean body weight was assumed as $70 \mathrm{~kg}$.

EWI (estimated weekly intake) was calculated according to the formula [18]:

$\mathrm{EWI}=\frac{\text { mean weekly consumption } \times \mathrm{Cd} \text { or } \mathrm{Pb} \text { content }}{\text { body weight }}$

(2) Chronic daily intake (CDI) of $\mathrm{Cd}$ or $\mathrm{Pb}$ was calculated according to the formula $[23,24]$ :

$\mathrm{CDI}=\frac{\mathrm{EDI} \times \mathrm{EFr} \times \mathrm{ED}_{\text {tot }}}{\text { body weight } \times \mathrm{AT}}$

where EDI is the estimated daily intake of $\mathrm{Cd}$ and $\mathrm{Pb}$, calculated on the basis of the mean weekly consumption of drinks (one, two or three cups) and mean level of $\mathrm{Cd}$ and $\mathrm{Pb}$; $\mathrm{EFr}$ is the days of exposure frequency (365 per year); $\mathrm{ED}_{\text {tot }}$ is the exposure duration (56 years); and AT is the period of exposure (365 per year).

(3) Target hazard quotient (THQ) was calculated according to the formula [23]:

$\mathrm{THQ}=\mathrm{CDI} / \mathrm{RfD}$

where $\mathrm{CDI}$ stands for daily intake of $\mathrm{Cd}$ or $\mathrm{Pb}$ with beverages.

The reference dose (RfD) for $\mathrm{Cd}$ is $1 \mu \mathrm{g} \mathrm{kg}-1$ of body weight per day, and for $\mathrm{Pb}$, it is $3.5 \mu \mathrm{g} \mathrm{kg}^{-1}$ of body weight per day [25].

(4) Hazard index (HI) was calculated from the formula [23]:

$$
\mathrm{HI}=\mathrm{THQCd}+\mathrm{THQPb}
$$

\section{Statistical Analysis}

Statistica 13.1 software was used for statistical analysis. The mean, minimum and maximum values, and the standard deviation (SD) were calculated and an analysis of variance was carried out. The calculations took into account three replications for each chemical analysis. Statistically significant differences $(P<0.05)$ were determined by oneway analysis of variance (ANOVA) using Duncan's test. 
Table 2 Characteristic of the analysed instant coffee

\begin{tabular}{|c|c|c|c|c|c|c|}
\hline Type of coffee & Coffee varieties & Trade mark & $\begin{array}{l}\text { Size of } \\
\text { pack- } \\
\text { age, g }\end{array}$ & $\begin{array}{l}\text { Size of } \\
\text { portion, } \\
\mathrm{g}\end{array}$ & Content of coffee & Made in \\
\hline Instant coffee & No data & A-1 & 200 & 2.8 & Instant coffee $100 \%$ & Holland \\
\hline Instant coffee & Arabica + Robusta & B-1 & 200 & 3.0 & Instant coffee $100 \%$ & Poland \\
\hline Instant coffee & No data & B-2 & 200 & 2.9 & Instant coffee $100 \%$ & Poland \\
\hline Instant coffee & Arabica & $\mathrm{C}-1$ & 100 & 3.1 & Instant coffee $100 \%$ & Poland \\
\hline Instant coffee & No data & $\mathrm{D}$ & 500 & 2.9 & Instant coffee $100 \%$ & Poland \\
\hline Instant coffee & Arabica & E-1 & 100 & 3.0 & Instant coffee $100 \%$ & Germany \\
\hline Instant coffee & Robusta & E-2 & 200 & 2.6 & Instant coffee $100 \%$ & Germany \\
\hline Instant coffee & No data & $\mathrm{F}$ & 50 & 3.0 & Instant coffee $100 \%$ & Germany \\
\hline Instant coffee & No data & $\mathrm{C}-2$ & 2.0 & 2.0 & Instant coffee $100 \%$ & Poland \\
\hline Instant coffee & Arabica & G & 1.8 & 1.8 & Instant coffee $100 \%$ & Poland \\
\hline Instant coffee & Arabica + Robusta & $\mathrm{C}-3$ & 2.0 & 2.0 & Instant coffee $100 \%$ & Poland \\
\hline $\begin{array}{l}\text { Blend of green and roasted instant } \\
\text { coffee }\end{array}$ & No data & B-3 & 20 & 3.2 & $\begin{array}{l}\text { Roasted instant coffee }(65 \%) \text {, green } \\
\text { coffee }(35 \%)\end{array}$ & Poland \\
\hline $\begin{array}{l}\text { Blend of green and roasted instant } \\
\text { coffee }\end{array}$ & No data & B-4 & 100 & 3.1 & $\begin{array}{l}\text { Roasted instant coffee }(65 \%) \text {, green } \\
\text { coffee }(35 \%)\end{array}$ & Poland \\
\hline $\begin{array}{l}\text { Blend of green and roasted instant } \\
\text { coffee }\end{array}$ & No data & C-4 & 12 & 12.0 & $\begin{array}{l}\text { Roasted instant coffee (12\%), green } \\
\text { coffee }(4 \%)\end{array}$ & Poland \\
\hline $\begin{array}{l}\text { Blend of green and roasted instant } \\
\text { coffee }\end{array}$ & No data & $\mathrm{H}$ & 500 & 3.3 & $\begin{array}{l}\text { Roasted instant coffee }(65 \%) \text {, green } \\
\text { coffee }(35 \%)\end{array}$ & Poland \\
\hline $\begin{array}{l}\text { Blend of green and roasted instant } \\
\text { coffee }\end{array}$ & Robusta & $\mathrm{C}-5$ & 20 & 20.0 & $\begin{array}{l}\text { Roasted instant coffee (65\%), green } \\
\text { coffee }(35 \%)\end{array}$ & Poland \\
\hline $\begin{array}{l}\text { Blend of green and roasted instant } \\
\text { coffee }\end{array}$ & No data & $\mathrm{I}-1$ & 250 & 3.3 & $\begin{array}{l}\text { Roasted instant coffee }(97.1 \%) \text {, green } \\
\text { coffee }(2.9 \%)\end{array}$ & Poland \\
\hline Cappuccino instant coffee & No data & $\mathrm{I}-2$ & 130 & 13.0 & Roasted instant coffee $(9.5 \%)$ & Poland \\
\hline Cappuccino instant coffee & No data & $\mathrm{J}-1$ & 110 & 12.7 & Roasted instant coffee (12\%) & Poland \\
\hline Cappuccino instant coffee & No data & $\mathrm{J}-2$ & 110 & 13.0 & Roasted instant coffee (7\%) & Poland \\
\hline Cappuccino instant coffee & No data & A-2 & 500 & 13.3 & Roasted instant coffee (3\%) & Holland \\
\hline Cappuccino instant coffee & No data & A-3 & 500 & 15.0 & Roasted instant coffee (3\%) & Holland \\
\hline Cappuccino instant coffee & No data & A-4 & 18 & 18.0 & Roasted instant coffee (3\%) & Holland \\
\hline Chicory instant drink & - & K-1 & 100 & 6.0 & Bio, roasted chicory root & Poland \\
\hline Chicory instant drink & - & $\mathrm{L}$ & 100 & 6.0 & Bio, roasted chicory root & Poland \\
\hline Chicory instant drink & - & M & 100 & 6.1 & Roasted chicory root & Poland \\
\hline Chicory instant drink & - & $\mathrm{J}-3$ & 200 & 6.3 & Bio, roasted chicory root & Poland \\
\hline Chicory instant drink & - & $\mathrm{N}-1$ & 25 & 25.0 & Roasted chicory root & Poland \\
\hline Chicory instant drink & - & $\mathrm{O}$ & 100 & 6.0 & Bio, roasted chicory root & Belgium \\
\hline $\begin{array}{l}\text { Blend of chicory and coffee instant } \\
\text { drink }\end{array}$ & No data & $\mathrm{N}-2$ & 100 & 6.3 & Chicory $60 \%$, coffee $40 \%$ & Poland \\
\hline $\begin{array}{l}\text { Blend of chicory and coffee instant } \\
\text { drink }\end{array}$ & No data & $\mathrm{J}-3$ & 180 & 5.2 & $\begin{array}{l}\text { Chicory } 30.8 \% \text {, coffee } 34.3 \% \text {, oligof- } \\
\text { ructose } 33 \%\end{array}$ & Poland \\
\hline $\begin{array}{l}\text { Blend of chicory and coffee instant } \\
\text { drink }\end{array}$ & No data & $\mathrm{P}$ & 100 & 4.0 & Chicory $60 \%$, coffee $40 \%$ & Poland \\
\hline $\begin{array}{l}\text { Blend of chicory and coffee instant } \\
\text { drink }\end{array}$ & No data & Q & 100 & 4.0 & Chicory $60 \%$, coffee $40 \%$ & Poland \\
\hline $\begin{array}{l}\text { Blend of chicory and coffee instant } \\
\text { drink }\end{array}$ & No data & $\mathrm{R}$ & 150 & 4.0 & Chicory $60 \%$, coffee $20 \%$, barley $20 \%$ & Poland \\
\hline Instant cereal coffee drink & - & $\mathrm{S}$ & 200 & 4.0 & Chicory $60 \%$, coffee $38 \%$ & Germany \\
\hline Instant cereal coffee drink & - & K-2 & 200 & 6.0 & $\begin{array}{l}\text { Rye and barley } 72 \% \text {, chicory, sugar } \\
\text { beet }\end{array}$ & Poland \\
\hline Instant cereal coffee drink & - & $\mathrm{K}-3$ & 200 & 6.4 & $\begin{array}{l}\text { Roasted barley } 50 \% \text {, chicory } 30 \% \text {, } \\
\text { spicle wheat } 20 \%\end{array}$ & Poland \\
\hline
\end{tabular}


Table 2 (continued)

\begin{tabular}{|c|c|c|c|c|c|c|}
\hline Type of coffee & Coffee varieties & Trade mark & $\begin{array}{l}\text { Size of } \\
\text { pack- } \\
\text { age, g }\end{array}$ & $\begin{array}{l}\text { Size of } \\
\text { portion, } \\
\mathrm{g}\end{array}$ & Content of coffee & Made in \\
\hline Instant cereal coffee drink & - & $\mathrm{T}-1$ & 4.2 & 4.2 & $\begin{array}{l}\text { Rye } 60 \% \text {, barley } 20 \% \text {, chicory and } \\
\text { white beet } 20 \%\end{array}$ & Poland \\
\hline Instant cereal coffee drink & - & $\mathrm{T}-2$ & 4.2 & 4.2 & Rye $50 \%$, chicory $50 \%$ & Poland \\
\hline Instant cereal coffee drink & - & $\mathrm{U}$ & 12 & 12.0 & $\begin{array}{l}\text { Roasted barley and rye } 16.5 \% \text {, instant } \\
\text { coffee } 12 \%\end{array}$ & Poland \\
\hline Instant cereal coffee drink & - & W & 120 & 7.0 & Roasted barley & Italy \\
\hline 2-in-1 instant coffee & No data & C-6 & 8.0 & 8.0 & Instant coffee $19 \%$ & Poland \\
\hline 2-in-1 instant coffee & No data & A-5 & 14 & 14.0 & Instant coffee $9.9 \%$ & Germany \\
\hline 2-in-1 instant coffee & No data & $\mathrm{X}$ & 18 & 18.0 & Instant coffee $10 \%$ & Poland \\
\hline 3-in-1 instant coffee & No data & B-5 & 20 & 20.0 & Instant coffee $10.1 \%$ & Poland \\
\hline 3-in-1 instant coffee & No data & $\mathrm{Y}$ & 18 & 18.0 & Instant coffee $11 \%$ & Poland \\
\hline 3-in-1 instant coffee & No data & $\mathrm{Z}$ & 15 & 15.0 & Instant coffee $15 \%$ & Poland \\
\hline 3-in-1 instant coffee & No data & A- 6 & 16 & 16.0 & Instant coffee $15 \%$ & Germany \\
\hline 3-in-1 instant coffee & No data & $\mathrm{C}-7$ & 17 & 17.0 & Instant coffee $12.2 \%$ & Poland \\
\hline
\end{tabular}

\section{Results}

\section{The Content of $\mathrm{Cd}$ and $\mathrm{Pb}$ in Instant Coffee, Instant Coffee Drinks and Instant Coffee Substitutes}

The content of $\mathrm{Cd}$ and $\mathrm{Pb}$ in the analysed beverages is presented in Table 3. The highest $(P<0.05)$ content of Cd was measured in chicory coffee $\left(3.202 \pm 0.7 \mu \mathrm{g} \mathrm{kg}^{-1}\right)$ and cereal coffee $\left(3.072 \pm 0.4 \mu \mathrm{g} \mathrm{kg}^{-1}\right)$. It was also significant in the chicory and natural roasted coffee blend $\left(2.820 \pm 0.9 \mu \mathrm{g} \mathrm{kg}^{-1}\right)$. The lowest $(P<0.05)$ content of $\mathrm{Cd}$ was found in cappuccino coffee drink and instant natural coffee less than $0.1 \mu \mathrm{g} \mathrm{kg}^{-1}$. The highest $(P<0.05)$ content of $\mathrm{Pb}$ was observed in instant natural coffee $\left(82.6 \pm 6.9 \mu \mathrm{g} \mathrm{kg}^{-1}\right)$ and the lowest $(P<0.05)$ in the chicory and natural coffee blend $\left(11 \pm 1.9 \mu \mathrm{g} \mathrm{kg}^{-1}\right)$.

Table 3 Content of $\mathrm{Cd}$ and $\mathrm{Pb}$ in instant coffee $(n=49)$

\begin{tabular}{|c|c|c|c|c|c|c|c|c|}
\hline & $\begin{array}{l}\text { Instant } \\
\text { coffee, } \\
n=11\end{array}$ & $\begin{array}{l}\text { Green and } \\
\text { roasted coffee, } \\
n=6\end{array}$ & Cappuccino, $n=6$ & $\begin{array}{l}\text { Chicory } \\
\text { instant drink, } \\
n=6\end{array}$ & $\begin{array}{l}\text { Chicory and } \\
\text { coffee, } n=5\end{array}$ & $\begin{array}{l}\text { Cereal coffee } \\
\text { drink, } n=7\end{array}$ & $\begin{array}{l}2 \text {-in-1 or } \\
3 \text {-in-1, } \\
n=8\end{array}$ & ANOVA $P$ \\
\hline \multicolumn{9}{|l|}{$\mathrm{Cd}, \mu \mathrm{g} \mathrm{kg}^{-1}$} \\
\hline Mean & $0.095^{\mathrm{e}}$ & $0.549^{c}$ & $0.030^{\mathrm{f}}$ & $3.202^{\mathrm{a}}$ & $2.820^{\mathrm{b}}$ & $3.072^{\mathrm{ab}}$ & $0.195^{\mathrm{d}}$ & 0.003 \\
\hline Maximum & $0.137^{\mathrm{e}}$ & $0.732^{\mathrm{c}}$ & $0.070^{f}$ & $4.319^{\mathrm{a}}$ & $4.012^{\mathrm{a}}$ & $3.580^{\mathrm{b}}$ & $0.351^{\mathrm{d}}$ & $<0.001$ \\
\hline Minimum & $0.067^{f}$ & $0.358^{\mathrm{d}}$ & $<\mathrm{LOQ}^{\mathrm{g}}$ & $2.289^{\mathrm{b}}$ & $1.987^{\mathrm{c}}$ & $2.653^{\mathrm{a}}$ & $0.124^{\mathrm{e}}$ & $<0.001$ \\
\hline Median & 0.085 & 0.585 & 0.040 & 3.024 & 2.471 & 2.840 & 0.151 & \\
\hline SD & 0.027 & 0.156 & 0.030 & 0.736 & 0.940 & 0.409 & 0.095 & \\
\hline Variance analysis & 0.001 & 0.024 & 0.001 & 0.542 & 0.883 & 0.167 & 0.009 & \\
\hline \multicolumn{9}{|l|}{$\mathrm{Pb}, \mu \mathrm{g} \mathrm{kg}^{-1}$} \\
\hline Mean & $82.64^{\mathrm{a}}$ & $70.94^{\mathrm{b}}$ & $25.42^{\mathrm{d}}$ & $41.85^{\mathrm{c}}$ & $11.00^{f}$ & $41.00^{c}$ & $12.52^{\mathrm{e}}$ & 0.002 \\
\hline Maximum & $88.81^{\mathrm{a}}$ & $85.12^{\mathrm{a}}$ & $27.54^{\mathrm{c}}$ & $48.91^{\mathrm{b}}$ & $13.33^{\mathrm{d}}$ & $44.69^{\mathrm{b}}$ & $13.22^{\mathrm{d}}$ & $<0.001$ \\
\hline Minimum & $73.22^{\mathrm{a}}$ & $54.32^{\mathrm{b}}$ & $22.34^{\mathrm{d}}$ & $35.82^{\mathrm{c}}$ & $9.010^{\mathrm{f}}$ & $38.78^{\mathrm{c}}$ & $11.87^{\mathrm{e}}$ & 0.001 \\
\hline Median & 86.73 & 69.82 & 26.01 & 41.03 & 10.25 & 39.98 & 12.38 & \\
\hline SD & 6.955 & 11.46 & 1.929 & 5.106 & 1.947 & 2.438 & 0.650 & \\
\hline Variance analysis & 48.37 & 131.3 & 3.722 & 26.08 & 3.790 & 5.943 & 0.423 & \\
\hline
\end{tabular}

Average values for 3 replications. Means with different superscripts in the same lines differ significantly at $P<0.05$ by Duncan's test. LOQ $\mathrm{Cd}=0.004 \mathrm{mg} \mathrm{kg}^{-1} ;$ LOQ $\mathrm{Pb}=0.03 \mathrm{mg} \mathrm{kg}^{-1}$

$S D$, standard deviation; $L O Q$, limit of quantitation 


\section{The Safety of Drinking Instant Coffee, Coffee Drinks and Coffee Substitutes}

Table 4 presents data concerning the estimated safety of coffee drinks according to three consumption patterns (one, two or three servings of coffee a day). The content of $\mathrm{Cd}$ and $\mathrm{Pb}$ in coffee servings is presented in Fig. 1.

\section{Pattern 1: One Serving per Day}

The EWI of Cd with instant coffee is $0.001 \mu \mathrm{g}$, which corresponds to $0.001 \%$ TWI; with cappuccino $0.003 \mu \mathrm{g}$ $(0.002 \%$ TWI); with a roasted coffee and green coffee blend $0.012 \mu \mathrm{g}(0.007 \%$ TWI); with '2-in-1' and '3-in-1' blends $0.021 \mu \mathrm{g}(0.012 \% \mathrm{TWI})$; with a chicory and natural coffee blend and cereal coffee about $0.11 \mu \mathrm{g}(0.06 \%$ TWI); and with a chicory drink $0.135 \mu \mathrm{g}$, which corresponds to $0.077 \%$ TWI. In no case did $\mathrm{CDI}(\mathrm{Cd})$ and THQ(Cd) exceed 0.017 . The highest estimated daily intake of $\mathrm{Pb}$ was observed for cappuccino, which corresponds to about $0.3 \%$ BMDL01 and about $0.8 \%$ BMDL10. For instant coffee, chicory drink and roasted and green coffee blend, EWI is ca. 1.6-1.7 $\mu \mathrm{g}$ (ca. 0.2\% BMDL01 and ca. $0.5 \%$ BMDL10). Drinking cereal coffee will result in a $\mathrm{Pb}$ intake of $1.49 \mu \mathrm{g}$ per week (ca. 0.2\% BMDL01 and ca. $0.5 \%$ BMDL10), whereas EWI for a natural coffee and chicory blend is $0.44 \mu \mathrm{g}$ (ca. $0.06 \%$ BMDL01 and $0.14 \%$ BMDL10). In no case did $\mathrm{CDI}(\mathrm{Pb})$ and THQ $(\mathrm{Pb})$ exceed

Table 4 Safety of coffee for consumption

\begin{tabular}{|c|c|c|c|c|c|c|c|c|c|c|c|c|c|c|}
\hline & \multicolumn{2}{|c|}{ Instant coffee } & \multicolumn{2}{|c|}{$\begin{array}{l}\text { Green and } \\
\text { roasted coffee }\end{array}$} & \multicolumn{2}{|c|}{ Cappuccino } & \multicolumn{2}{|c|}{$\begin{array}{l}\text { Chicory instant } \\
\text { drink }\end{array}$} & \multicolumn{2}{|c|}{$\begin{array}{l}\text { Chicory and } \\
\text { coffee }\end{array}$} & \multicolumn{2}{|c|}{$\begin{array}{l}\text { Cereal coffee } \\
\text { drink }\end{array}$} & \multicolumn{2}{|c|}{$\begin{array}{l}2 \text { in } 1 \text { or } 3 \\
\text { in } 1\end{array}$} \\
\hline & $\mathrm{Cd}$ & $\mathrm{Pb}$ & $\mathrm{Cd}$ & $\mathrm{Pb}$ & $\mathrm{Cd}$ & $\mathrm{Pb}$ & $\mathrm{Cd}$ & $\mathrm{Pb}$ & $\mathrm{Cd}$ & $\mathrm{Pb}$ & $\mathrm{Cd}$ & $\mathrm{Pb}$ & $\mathrm{Cd}$ & $\mathrm{Pb}$ \\
\hline \multicolumn{15}{|c|}{ Pattern 1: drinking 1 cup of coffee a day } \\
\hline EWI, $\mu g^{1}$ & 0.002 & 1.685 & 0.012 & 1.564 & 0.003 & 2.521 & 0.135 & 1.767 & 0.114 & 0.443 & 0.112 & 1.492 & 0.021 & 1.369 \\
\hline$\% \mathrm{TWI}^{\mathrm{A}, \mathrm{B}}$ & 0.001 & & 0.007 & & 0.002 & & 0.077 & & 0.065 & & 0.064 & & 0.012 & \\
\hline$\% \mathrm{BMDL}^{\mathrm{A}, \mathrm{D}}$ & & 0.229 & & 0.213 & & 0.343 & & 0.240 & & 0.060 & & 0.203 & & 0.186 \\
\hline$\% \mathrm{BMDL} 10^{\mathrm{A}, \mathrm{C}}$ & & 0.547 & & 0.508 & & 0.818 & & 0.574 & & 0.144 & & 0.485 & & 0.445 \\
\hline $\mathrm{CDI}^{2}$ & $3 \times 10^{-4}$ & 0.254 & 0.002 & 0.236 & $4 \times 10^{-4}$ & 0.381 & 0.020 & 0.267 & 0.017 & 0.067 & 0.017 & 0.225 & 0.003 & 0.207 \\
\hline $\mathrm{THQ}^{3}$ & $3 \times 10^{-4}$ & 0.073 & 0.002 & 0.067 & $4 \times 10^{-4}$ & 0.109 & 0.020 & 0.076 & 0.017 & 0.019 & 0.017 & 0.064 & 0.003 & 0.059 \\
\hline $\mathrm{HI}^{4}$ & 0.073 & & 0.069 & & 0.109 & & 0.097 & & 0.036 & & 0.081 & & 0.062 & \\
\hline \multicolumn{15}{|c|}{ Pattern 2: drinking 2 cups of coffee a day } \\
\hline EWI, $\mu g^{1}$ & 0.004 & 3.370 & 0.024 & 3.128 & 0.006 & 5.042 & 0.270 & 3.535 & 0.227 & 0.886 & 0.224 & 2.985 & 0.043 & 2.739 \\
\hline$\% \mathrm{TWI}^{\mathrm{A}, \mathrm{B}}$ & 0.002 & & 0.014 & & 0.003 & & 0.155 & & 0.130 & & 0.128 & & 0.024 & \\
\hline$\% \mathrm{BMDL}^{\mathrm{A}} 1^{\mathrm{A}, \mathrm{D}}$ & & 0.463 & & 0.430 & & 0.693 & & 0.486 & & 0.122 & & 0.410 & & 0.376 \\
\hline$\%$ BMDL10 $10^{\mathrm{A}, \mathrm{C}}$ & & 1.094 & & 1.016 & & 1.637 & & 1.148 & & 0.288 & & 0.969 & & 0.889 \\
\hline $\mathrm{CDI}^{2}$ & 0.001 & 0.509 & 0.004 & 0.472 & 0.001 & 0.761 & 0.041 & 0.534 & 0.034 & 0.134 & 0.034 & 0.451 & 0.006 & 0.414 \\
\hline $\mathrm{THQ}^{3}$ & 0.001 & 0.145 & 0.004 & 0.135 & 0.001 & 0.218 & 0.041 & 0.153 & 0.034 & 0.038 & 0.034 & 0.129 & 0.006 & 0.118 \\
\hline $\mathrm{HI}^{4}$ & 0.146 & & 0.139 & & 0.218 & & 0.193 & & 0.072 & & 0.163 & & 0.125 & \\
\hline \multicolumn{15}{|c|}{ Pattern 3: drinking 3 cups of coffee a day } \\
\hline EWI, $\mu \mathrm{g}^{1}$ & 0.006 & 5.054 & 0.036 & 4.693 & 0.009 & 7.562 & 0.406 & 5.302 & 0.341 & 1.328 & 0.335 & 4.477 & 0.064 & 4.108 \\
\hline$\% \mathrm{TWI}^{\mathrm{A}, \mathrm{B}}$ & 0.003 & & 0.021 & & 0.005 & & 0.232 & & 0.195 & & 0.192 & & 0.036 & \\
\hline$\% \mathrm{BMDL}^{\mathrm{A}} 1^{\mathrm{A}, \mathrm{D}}$ & & 0.688 & & 0.638 & & 1.029 & & 0.721 & & 0.181 & & 0.609 & & 0.559 \\
\hline$\%$ BMDL $10^{\mathrm{A}, \mathrm{C}}$ & & 1.641 & & 1.524 & & 2.455 & & 1.722 & & 0.431 & & 1.454 & & 1.334 \\
\hline $\mathrm{CDI}^{2}$ & 0.001 & 0.763 & 0.005 & 0.709 & 0.001 & 1.142 & 0.061 & 0.801 & 0.051 & 0.201 & 0.051 & 0.676 & 0.010 & 0.620 \\
\hline $\mathrm{THQ}^{3}$ & 0.001 & 0.218 & 0.005 & 0.202 & 0.001 & 0.326 & 0.061 & 0.229 & 0.051 & 0.057 & 0.051 & 0.193 & 0.010 & 0.177 \\
\hline $\mathrm{HI}^{4}$ & 0.219 & & 0.208 & & 0.328 & & 0.290 & & 0.108 & & 0.244 & & 0.187 & \\
\hline
\end{tabular}

${ }^{\mathrm{A}}$ Mean body weight was assumed as $70 \mathrm{~kg}$

${ }^{\mathrm{B}} \mathrm{TWI}-2.5 \mu \mathrm{g}$ Cd per $\mathrm{kg}$ of body weight per week [21]

${ }^{\mathrm{C}} \mathrm{BMDL01}-10.5 \mu \mathrm{g} \mathrm{Pb}$ per kg of body weight per week [22]

${ }^{\mathrm{D}} \mathrm{BMDL} 10-4.4 \mu \mathrm{g} \mathrm{Pb}$ per $\mathrm{kg}$ of body weight per week [22]

${ }^{1} \mathrm{EWI}$ - estimated weekly intake calculated on the basis of the mean weekly consumption of coffee infusions and mean level of $\mathrm{Cd}$ and $\mathrm{Pb}$

${ }^{2} \mathrm{Chronic}$ daily intake calculated on the basis of the mean weekly consumption of coffee, mean level of $\mathrm{Cd}$ and $\mathrm{Pb}$, and exposure duration

${ }^{3}$ Target hazard quotient calculated on the basis of the chronic daily intake of $\mathrm{Cd}$ or $\mathrm{Pb}$

${ }^{4} \mathrm{Hazard}$ index is the sum of THQ for $\mathrm{Cd}$ and $\mathrm{Pb}$ 


\section{Cd, $\mu g$}
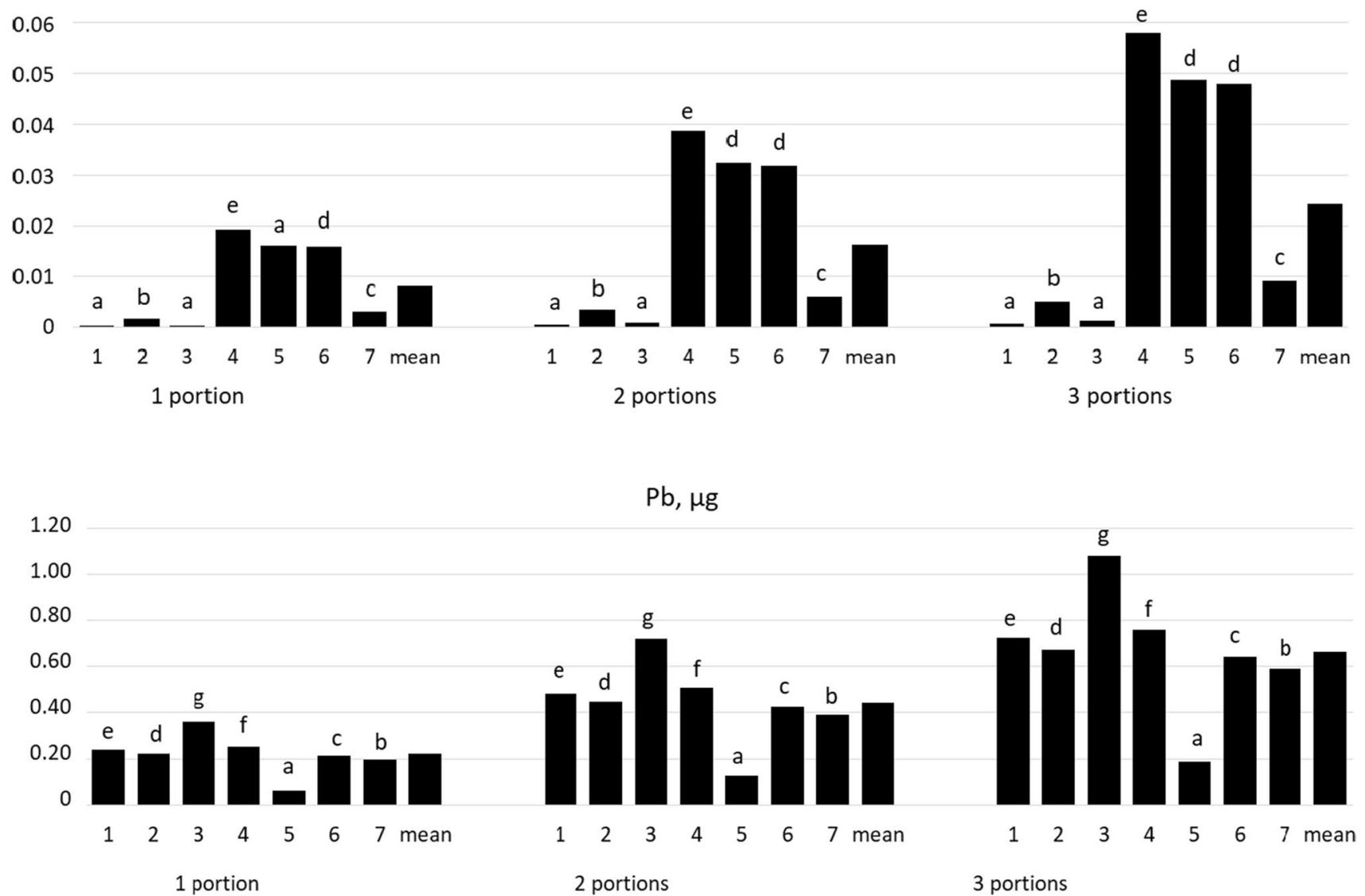

Fig. 1 Mean $\mathrm{Cd}$ and $\mathrm{Pb}$ content in 1, 2 and 3 portions of instant coffee, coffee drinks and coffee substitutes. 1-instant coffee; 2 -green and roasted coffee; 3-cappuccino; 4-chicory instant drink; 5-

chicory and coffee; 6 - cereal coffee drink; $7-2$ in 1 and 3 in 1 . Values with different superscripts differ at $P<0.05$ by Duncan's test

$\mathrm{HI}(\mathrm{Cd}+\mathrm{Pb})$ ranged from 0.072 (chicory and natural coffee blend) to 0.218 (cappuccino).

\section{Pattern 3: Three Servings per Day}

For Cd, EWI with instant coffee and with cappuccino is lower than $0.01 \mu \mathrm{g}(\max .0 .05 \% \mathrm{TWI})$, with a green and roasted coffee blend $0.036 \mu \mathrm{g}(0.02 \% \mathrm{TWI})$, with '2-in-1' and ' 3 -in-1' blends $0.064 \mu \mathrm{g}(0.036 \% \mathrm{TWI})$, with a chicory and roasted coffee blend and with a roasted grain drink ca. $0.34 \mu \mathrm{g}$ (ca. $0.2 \% \mathrm{TWI}$ ), and with a chicory drink more than $0.4 \mu \mathrm{g}$, which corresponds to above $0.2 \%$ TWI. In no case did $\mathrm{CDI}(\mathrm{Cd})$ and THQ $(\mathrm{Cd})$ exceed 0.07 . For $\mathrm{Pb}$, EWI with a chicory and natural coffee blend amounted to ca. $1.3 \mu \mathrm{g}$ (0.18\% BMDL01, 0.4\% BMDL10). With a green and roasted coffee blend and with a roasted grain drink and '2-in-1' and '3-in-1' blends, EWI was about 4.1-4.7 $\mu \mathrm{g}$ (max. 0.64\% BMDL01, max. 1.5\% BMDL10). With natural coffee and chicory drink, one can consume a little more than $5 \mu \mathrm{g} \mathrm{Pb}$ per week (ca. 0.7\% BMDL01, max. 1.73\% BMDL10), while 
with cappuccino more than $7.5 \mu \mathrm{g} \mathrm{Pb}$ (ca. 1.0\% BMDL01, ca. $2.5 \%$ BMDL10). The value of $\mathrm{CDI}(\mathrm{Pb})$ did not exceed 0.8 and only for cappuccino was it above 1.15 . The value of $\mathrm{THQ}(\mathrm{Pb})$ did not exceed 0.33 . The $\mathrm{HI}(\mathrm{Cd}+\mathrm{Pb})$ ranged from 0.108 (chicory and natural coffee blend) to 0.328 (cappuccino).

\section{Discussion}

People like coffee drinks (instant coffee, cappuccino, coffee blends) and coffee substitutes (cereal coffee, decaffeinated coffee) since they can be easily prepared and taste good [1]. In Poland, instant coffee drinks are as popular as cereal coffee-being the choice of about $50 \%$ of coffee drinkers [ 1 , $8,12]$. Nevertheless, it has not been thoroughly examined whether instant coffee is safe to drink, as implied by limited references on this subject. Analysis of available literature showed that only about $4 \%$ of all the references investigating the content of heavy metals in coffee refer to instant coffee. Perhaps this is due to the fact that instant coffee drinks are not popular in many countries; for instance, in the Balkans, the most popular choice is traditionally brewed coffee [26].

In our study, instant products containing natural coffee contained on average from six (a blend of green and roasted instant coffee) up to 100 (cappuccino) times less Cd per $1 \mathrm{~kg}$ than the beverages containing chicory and roasted grains. No directional relationship was identified for $\mathrm{Pb}$ between its content and the ingredients of the beverage; however, $100 \%$ coffee beverages (instant coffee, a blend of green and roasted coffee) contained several times more $\mathrm{Pb}$ than other analysed beverages did. The maximum level of $\mathrm{Cd}$ in the analysed beverages amounted to $4.3 \mu \mathrm{g}$ (chicory instant drink), and that of $\mathrm{Pb} 88.8 \mu \mathrm{g}$ (instant coffee) per $1 \mathrm{~kg}$, which corresponds to $0.004 \mathrm{mg} \mathrm{Cd}$ and $0.089 \mathrm{mg} \mathrm{Pb}$ per $1 \mathrm{~kg}$. Grembecka et al. [27] analysed as many as 120 samples of different kinds of coffee, including 27 samples of instant coffee. The abovementioned authors found that the content of $\mathrm{Cd}$ and $\mathrm{Pb}$ could not be determined using the applied method of analysis (LOD Cd $=0.003 \mathrm{mg} 100 \mathrm{~g}^{-1}, \mathrm{LOD} \mathrm{Pb}=0.01 \mathrm{mg}$ $\left.100 \mathrm{~g}^{-1}\right)$. Gogoasa et al. [28, 29] obtained similar results for several types of instant coffee available on the market in Romania. Studies by Alkherraz et al. [30] showed the content of Cd in instant coffee was ND- $-0.3 \mathrm{mg} \mathrm{kg}^{-1}$ and that of $\mathrm{Pb}$ was ND-3.9 mg kg${ }^{-1}$. The maximum values were significantly higher than in our studies. Voica et al. [31] found instant coffee to contain a maximum of $0.002 \mathrm{mg} \mathrm{Cd}$ and $0.12-0.37 \mathrm{mg} \mathrm{Pb}$. Studies into instant coffee drinks (2-in-1, 3-in-1, 4-in-1 and instant iced coffee) offered on the market in Serbia revealed that they contained a maximum of $0.01 \mathrm{ppm}$ of $\mathrm{Cd}$ [26], so they are safe for consumers. In the abovementioned studies, determinable levels of $\mathrm{Cd}$ were measured only in 2 out of 15 samples of coffee drinks.
It should be emphasised that our studies found coffee drinks and coffee substitutes safe for consumers. Even with three servings a day of beverage containing the highest level of $\mathrm{Cd}$ (chicory drink, cereal coffee or a blend of chicory and natural coffee) or $\mathrm{Pb}$ (instant coffee, a blend of green and roasted coffee), the indicators of safety (CDI, THQ, HI) do not exceed 0.35 for $\mathrm{Cd}$ and 0.8 for $\mathrm{Pb}$, which means that the risk of diseases related to chronic exposure to $\mathrm{Cd}$ and $\mathrm{Pb}$ consumed with coffee is very low. However, $\mathrm{CDI}(\mathrm{Pb})$ for cappuccino was higher than 1 , which is a red flag; that was due to serving size, as one serving of cappuccino weighs more than $14 \mathrm{~g}$, while for other beverages, it is about 3-4 times lower (except blends weighing more than $15 \mathrm{~g}$ ). This poses a particular hazard as, during complex exposure $(\mathrm{Cd}+\mathrm{Pb}), \mathrm{Pb}$ accumulates in body organs at amounts higher than $\mathrm{Cd}$, which was proved in studies involving rats [19]. It should be noted that cappuccino is one of the favourite coffee types in Poland, chosen by more than $84 \%$ of consumers [12]. In our studies, $\mathrm{CDI}(\mathrm{Pb})$ was also high for an instant chicory drink. Its value exceeded 0.8 , and above 1 is considered a hazardous level. A chicory substitute of coffee is caffeine free and is suitable for children [32], which poses a particular risk to a young and sensitive body. Due to the presence of oligosaccharides (mainly inulin), a chicory drink has a pleasant, sweetish taste [33] that is accepted even by small children who show innate preferences for sweet taste [34].

In our studies, the percentage of tolerable intake of $\mathrm{Cd}$ and $\mathrm{Pb}$ with the analysed beverages did not exceed $2.5 \%$, as recommended by EFSA [21, 22]. Other studies also corroborated that instant coffee drinks and their substitutes were safe for consumers [26, 27, 31]. It is worth noting that drinking instant coffee drinks and their substitutes is as safe as drinking roasted coffee brews, and numerous studies in many countries have corroborated that drinking roasted coffee is safe $[17,18,35,36]$. However, it should be noted that some authors $[17,37]$ found $\mathrm{Pb}$ levels exceeding the tolerable value in as much as $75 \%$ of the analysed roasted coffee samples. Such information was not found in available literature for instant coffee. Our previous studies demonstrated that dry roasted coffee contained on average $3.78 \mu \mathrm{g} \mathrm{Cd}$ and $49.6 \mu \mathrm{g} \mathrm{Pb}$ per $1 \mathrm{~kg}$ [18]. In the abovementioned studies, on average, $95 \%$ of $\mathrm{Cd}$ and $94 \%$ of $\mathrm{Pb}$ penetrated into the solution, which means that one serving of coffee brew contained on average $0.16 \mu \mathrm{g} \mathrm{Cd}$ and $1.97 \mu \mathrm{g} \mathrm{Pb}$, whereas one serving of instant coffee on average $0.008 \mu \mathrm{g} \mathrm{Cd}$ and $0.22 \mu \mathrm{g} \mathrm{Pb}$ (Fig. 1), that is, twenty times less $\mathrm{Cd}$ and nine times more $\mathrm{Pb}$ than in a ground coffee brew. Also, reviews by Pohl et al. [38] showed that dry roasted coffee contained several times more $\mathrm{Cd}$ and $\mathrm{Pb}$ than instant coffee did; considering the percentage of $\mathrm{Cd}$ and $\mathrm{Pb}$ penetrating into the beverage (94-95\%), a roasted coffee brew contains more $\mathrm{Cd}$ and $\mathrm{Pb}$ than an instant coffee drink. For frequent coffee 
drinkers, this may have a significant effect on the intake of $\mathrm{Cd}$ and $\mathrm{Pb}$ with the diet, although it was demonstrated that drinking as many as three servings of roasted coffee per day (one serving: $6 \mathrm{~g}$ of ground coffee $+100 \mathrm{~mL}$ of water) still does not lead to exceeding the tolerable limits [18]. Differences in the coffee production process can give rise to differences in the content of heavy metals in instant and ground coffee. Ground coffee is made by roasting and drying coffee beans, while instant coffee is produced by evaporating water (through freeze-drying or spray drying) from a concentrated roasted coffee brew [39, 40]. Coffee brews usually contain smaller concentrations of elements than the corresponding roasted coffees from which the brews were prepared [38].

To sum up, the content of $\mathrm{Cd}$ and $\mathrm{Pb}$ in the analysed coffee beverages and coffee substitutes was low; thus, drinking such beverages is safe for consumers. However, no safe limits of heavy metal intake exist due to the ability of such metals to accumulate in living tissues (half-life up to 30 years), so beverages and food should be regularly monitored for heavy metals. With instant drinks, special note should be taken of $\mathrm{Pb}$, as the level of this metal is higher than that of $\mathrm{Cd}$, and for beverages with higher weight per serving (e.g. cappuccino), the intake of $\mathrm{Pb}$ can exceed consumer-safe levels if they are consumed on a regular basis. Therefore, it should be considered whether it is advisable that flavoured multi-ingredient instant coffee drinks be consumed from time to time only, and natural coffee with optional milk and/ or sweeteners be the choice of regular coffee drinkers.

Author Contribution Conceptualization: Anna Winiarska-Mieczan; methodology: Anna Winiarska-Mieczan, Karolina Jachimowicz; formal analysis and investigation: Svitlana Kislova, Małgorzata Kwiecień; writing-original draught preparation: Anna WiniarskaMieczan; writing - review and editing: Karolina Jachimowicz, Zvenyslava Zasadna; funding acquisition: Dmytro Yanovych; resources: Anna Winiarska-Mieczan, Małgorzata Kwiecień; supervision: Anna Winiarska-Mieczan.

\section{Declarations}

Ethics Approval Not applicable.

Consent to Participate All authors reviewed and approved the final manuscript.

Consent for Publication All authors approved for this publication.

Conflict of Interest The authors declare no competing interests.

Open Access This article is licensed under a Creative Commons Attribution 4.0 International License, which permits use, sharing, adaptation, distribution and reproduction in any medium or format, as long as you give appropriate credit to the original author(s) and the source, provide a link to the Creative Commons licence, and indicate if changes were made. The images or other third party material in this article are included in the article's Creative Commons licence, unless indicated otherwise in a credit line to the material. If material is not included in the article's Creative Commons licence and your intended use is not permitted by statutory regulation or exceeds the permitted use, you will need to obtain permission directly from the copyright holder. To view a copy of this licence, visit http://creativecommons.org/licenses/by/4.0/.

\section{References}

1. Kwiatkowska K, Winiarska-Mieczan A, Kwiecień M, Klebaniuk R, Krusiński R, Rusinek-Prystupa E, Sembratowicz I, Kamińska E, Danek-Majewska A, Cholewińska E (2017) Analysis of coffee consumption among primary school teachers. Probl Hig Epidemiol 98:285-289

2. Martini D, Del Bo' C, Tassotti M, Riso P, Del Rio D, Brighenti F, Porrini M (2016) Coffee consumption and oxidative stress: a review of human intervention studies. Molecules 21:979. https://doi.org/10.3390/molecules21080979

3. Nkondjock A (2009) Coffee consumption and the risk of cancer: an overview. Cancer Lett 277:121-125. https://doi.org/10. 1016/j.canlet.2008.08.022

4. Huxley R, Lee CM, Barzi F, Timmermeister L, Czernichow S, Perkovic V, Grobbee DE, Batty D, Woodward M (2009) Coffee, decaffeinated coffee, and tea consumption in relation to incident type 2 diabetes mellitus: a systematic review with meta-analysis. Arch Intern Med 169:2053-2063. https://doi.org/10.1001/ archinternmed.2009.439

5. Sääksjärvi K, Knekt P, Rissanen H, Laaksonen MA, Reunanen A, Männistö S (2008) Prospective study of coffee consumption and risk of Parkinson's disease. Eur J Clin Nutr 62:908-915. https://doi.org/10.1038/sj.ejcn.1602788

6. Torres-Collado L, Compañ-Gabucio LM, González-Palacios S, Notario-Barandiaran L, Oncina-Cánovas A, Vioque J, García-de la Hera M (2021) Coffee consumption and all-cause, cardiovascular, and cancer mortality in an adult mediterranean population. Nutrients 13:1241. https://doi.org/10.3390/nu13041241

7. Kim J, Kim J (2018) Green tea, coffee, and caffeine consumption are inversely associated with self-report lifetime depression in the Korean population. Nutrients 10:1201. https://doi.org/10. 3390/nu10091201

8. Chudy S (2014) Development of coffee market and changes in coffee consumption among Poles. J Agribus Rural Develop 34:41-51

9. Statistical Yearbook of the Republic of Poland (2020) Statistical Publishing Establishment. Warsaw, Poland

10 Alba Talero LH, Peñaloza MJ, Gutiérrez VC, Juan S (2018) Effect of habitual coffee consumption on cardiovascular health: protocol for a review of systematic reviews of the literature. Universitas Médica 60:1-6. https://doi.org/10.11144/Javeriana.umed60-2.café

11. Wachamo HL (2017) Review on health benefit and risk of coffee consumption. Med Aromat Plants 6:301. https://doi.org/10.4172/ 2167-0412.1000301

12. Czarniecka-Skubina E, Pielak M, Sałek P, Korzeniowska-Ginter R, Owczarek T (2021) Consumer choices and habits related to coffee consumption by Poles. Int J Environ Res Public Health 18:3948. https://doi.org/10.3390/ijerph18083948

13. Mokrysz S (2017) Consumer preferences with regard to thekinds of coffee and brands of ground coffee available on the Polish market. Zesz Nauk Uniw Ekon Katow 330:128-138

14. Wierzejska R (2010) Coffee-does it harm or help? Przem Spoż 12:18-22

15. Długaszek M, Połeć J, Mularczyk-Oliwa M (2010) The content of chosen elements in coffee infusions depending on the method of their preparation. Bromat Chem Toksykol 43:493-497 
16. Gökcen BB, Şanlier N (2017) Coffee consumption and disease correlations. Crit Rev Food Sci Nutr 59:336-348. https://doi.org/ 10.1080/10408398.2017.1369391

17. Pigozzi MT, Passos FR, Mendes FQ (2018) Quality of commercial coffees: heavy metal and ash contents. J Food Qual 2018:5908463. https://doi.org/10.1155/2018/5908463

18. Winiarska-Mieczan A, Kwiatkowska K, Kwiecień M, Zaricka E (2021) Assessment of the risk of exposure to cadmium and lead as a result of the consumption of coffee infusions. Biol Trace Elem Res 199:2420-2428. https://link.springer.com/article/10.1007/ s12011-020-02332-3

19. Winiarska-Mieczan A, Kwiecień M (2016) The effect of exposure to $\mathrm{Cd}$ and $\mathrm{Pb}$ in the form of a drinking water or feed on the accumulation and distribution of these metals in the organs of growing Wistar rats. Biol Trace Elem Res 169:230-236. https://doi.org/10. 1007/s12011-015-0414-4

20. Winiarska-Mieczan A, Grela ER (2017) Content of cadmium and lead in raw, fried and baked commercial frozen fishery products consumed in Poland. J Sci Food Agric 97:2969-2974. https://doi. org/10.1007/s12011-017-1104-1

21. EFSA (2012) Cadmium dietary exposure in the European population. EFSA J 10(1):2551. https://doi.org/10.2903/j.efsa.2012.2551

22. EFSA (2012) Lead dietary exposure in the European population. EFSA J 10(7):2831. https://doi.org/10.2903/j.efsa.2012.2831

23. Sultana MS, Rana S, Yamazaki S, Aono T, Yoshida S (2017) Health risk assessment for carcinogenic and noncarcinogenic heavy metal exposures from vegetables and fruits of Bangladesh. Cog Environ Sci 3:1291107. https://doi.org/10.1080/23311843. 2017.1291107

24. Issa AB, Yasin K, Loutfy N, Ahmed MT (2018) Risk assessment of heavy metals associated with food onsumption in Egypt: a pilot study. J Clin Exp Tox 2:15-24. https://doi.org/10.4066/ 2630-4570.011

25. Song D, Zhuang D, Jiang D, Fu J, Wang Q (2015) Integrated health risk assessment of heavy metals in Suxian County, South China. Int J Environ Res Public Health 12:7100-7117. https://doi. org/10.3390/ijerph120707100

26. Petrović SM, Savić SR, Zvezdanović JB, MladenovićRanisavljević I, Cvetković DJ, Cvetanović AD (2019) Benefts and risks of commercially available coffee beverages from Western Balkan. Chem Pap 74:847-857. https://doi.org/10.1007/ s11696-019-00916-5

27. Grembecka M, Malinowska E, Szefer P (2007) Differentiation of market coffee and its infusions in view of their mineral composition. Sci Total Environ 383:59-69. https://doi.org/10.1016/j.scito tenv.2007.04.031

28. Gogoasa I, Pirvu A, Alda L, Velciov A, Rada M, Bordean DM, Moigradean D, Simion A, Gergen I (2013) The mineral content of different coffee brands. J Hortic For Biotechnol 17:68-71
29. Gogoasa I, Berbecea A, Negrea A, Rada M, Cozma A, Alda LM, Bordean DM, Danci M, Alda S (2017) Determination of trace elements in commercially available instant coffees. J Hortic For Biotechnol 21:1-5

30. Alkherraz AM, Hasbad OM, Elsherif KM (2019) Heavy metals contents in some commercially available coffee, tea, and cocoa samples in Misurata City_Libya. Prog Chem Biochem Res 2:99_ 107. https://doi.org/10.33945/SAMI/PCBR.2019.2.3.3

31. Voica C, Feher I, Iordache AM, Cristea G, Dehelean A, Magdas DA, Mirel V (2016) Multielemental analysis of coffee by inductively coupled plasma-mass spectrometry. Anal Lett 49:26272643. https://doi.org/10.1080/00032719.2015.1116003

32. Gielecińska I, Mojska H, Świderska K (2017) Coffee substitutes as a dietary source of acrylamide. Probl Hig Epidemiol 98:290-295

33. Jurgoński A, Milala J, Juśkiewicz J, Zduńczyk Z, Król B (2011) Composition of chicory root, peel, seed and leaf ethanol extracts and biological properties of their non-inulin fractions. Food Technol Biotechnol 49:40-47

34. Sobek G, Łuszczki E, Dąbrowski M, Dereń K, Baran J, Weres A, Mazur A (2020) Preferences for sweet and fatty taste in children and their mothers in association with weight status. Int J Environ Res Public Health 17:538. https://doi.org/10.3390/ijerph17020538

35. Şemen S, Mercan S, Yayla M, Açıkkol M (2017) Elemental composition of green coffee and its contribution to dietary intake. Food Chem 215:92-100. https://doi.org/10.1016/j.foodchem. 2016.07.176

36. Suseela B, Bhalke S, Kumar AV, Tripathi RM, Sastry VN (2001) Daily intake of trace metals through coffee consumption in India. Food Addit Contam 18:115-120. https://doi.org/10.1080/02652 030010008814

37. da Silva SA, Mendes FQ, Reis MR, Passos FR, de Carvalho AMX, de Oliveira Rocha KR, Pinto FG (2017) Determination of heavy metals in the roasted and ground coffee beans and brew. Afr J Agric Res 12:221-228. https://doi.org/10.5897/AJAR2016.11832

38. Pohl P, Stelmach E, Welna M, Szymczycha-Madeja A (2013) Determination of the elemental composition of coffee using instrumental methods. Food Anal Met 6:598-613. https://doi. org/10.1007/s12161-012-9467-6

39. Burmester K, Pietsch A, Eggers R (2011) A basic investigation on instant coffee production by vacuum belt drying. Proc Food Sci 1:1344-1352. https://doi.org/10.1016/j.profoo.2011.09.199

40. Mussatto SI, Machado EM, Martins S, Teixeira JA (2011) Production, composition, and application of coffee and its industrial residues. Food Biopr Technol 4:661-672. https://doi.org/10.1007/ s11947-011-0565-Z

Publisher's Note Springer Nature remains neutral with regard to jurisdictional claims in published maps and institutional affiliations. 